\title{
A field survey of soil pH and extractable aluminium in the Ashburton Lakes Catchment, Canterbury, New Zealand
}

\author{
A.E. WHITLEY, P.C. ALMOND, J.L. MOIR, M. GIONA BUCCI, J. NELSON and D.J. MOOT \\ Faculty of Agriculture and Life Sciences \\ Lincoln University, PO Box 84, Lincoln, Canterbury, New Zealand \\ amyewhitley1@gmail.com
}

\begin{abstract}
Soil extractable aluminium (Al) concentrations have a strong impact on the establishment, growth and persistence of pasture legumes. A survey of 21 soil profiles in the Ashburton Lakes catchment was conducted to determine the key factors driving extractable $\mathrm{Al}$ concentrations. The mean $\mathrm{Al}(0.02 \mathrm{M}$ $\mathrm{CaCl}_{2}$ ) concentration was $7.8 \mathrm{mg} / \mathrm{kg}$ with the highest values in the top $50 \mathrm{~cm}$ of the soil profile. However, there was considerable variation among sites. Landform age, rainfall and depth were all important variables for extractable $\mathrm{Al}$ (but $\mathrm{R}^{2}$ was low), while landform type was not. The highest $\mathrm{Al}$ concentrations in the $20 \mathrm{~cm}$ depth zone were found at the wettest sites in the catchment where rainfall was $\geq 1266 \mathrm{~mm}$ and where $\mathrm{pH}$ was lowest. Farmers in this catchment could use this knowledge to determine which areas of their farms are most susceptible to elevated $\mathrm{Al}$ concentrations and at what depth. This would assist in determining which areas could be targeted for development and which are unsuitable.
\end{abstract}

Keywords: acidic soils, toxicity, soil profile depth, rainfall, landform type, geologic age, elevation, aspect, slope

\section{Introduction}

In the New Zealand high and hill-country soil acidity and low fertility (N, P and S) limit the growth and establishment of legumes (Haynes \& Williams 1993), which provide $\mathrm{N}$ to the system and are a high quality feed for grazing stock. Soil extractable aluminium (Al) concentrations play an important role in the viability of pasture and forage legumes in these environments.

The few studies conducted in New Zealand examining the drivers of soil $\mathrm{pH}$ and $\mathrm{Al}$ variability focused on differences in chemistry of soils on landforms of different age and type. These studies were conducted along rainfall (climosequence) or age gradients (chronosequence). Webb et al. (1986) found that weathering and soil development increased with an increase in rainfall (640 to $2000 \mathrm{~mm} /$ year) at four sites in the McKenzie basin. Soil pH declined with an increase in rainfall as a result of the leaching of bases, and $\mathrm{Al}(1 \mathrm{M} \mathrm{KCl}$ extracted $\mathrm{Al})$ concentration increased between the lowest and highest rainfall sites.
Harrison et al. (1990) examined chronosequences of soils in the Puffer stream terrace sequence $(830 \mathrm{~mm} /$ year) and on moraines on the Craigieburn Range (1447 $\mathrm{mm} /$ year) in the Waimakariri basin. Both increasing rainfall and age increased soil $\mathrm{Al}(1 \mathrm{M} \mathrm{KCl}$ extracted $\mathrm{Al})$ concentrations. Dixon et al. (2016) examined the climate driven thresholds for chemical weathering at 28 profile sites close to the sites sampled by Webb et al. (1986) along the McKenzie Basin climate gradient, with mean annual rainfall ranging from 400 to 4700 $\mathrm{mm} /$ year. Dixon et al. (2016) did not report extractable $\mathrm{Al}\left(1 \mathrm{M} \mathrm{KCl}\right.$ or $\left.0.02 \mathrm{M} \mathrm{CaCl}_{2}\right)$, but noted threshold behaviour related to mean annual rainfall with trivalent metallic ions and other variables.

These studies all indicate potential variability of soil extractable Al related to landscape and environmental attributes yet there has been no systematic study of extractable Al variability at this scale. Moreover, to mitigate $\mathrm{Al}$ toxicity an understanding is needed as to which soils are most susceptible and what factors are involved other than soil $\mathrm{pH}$. Therefore, the objective of this work was to determine the key factors driving variation in soil extractable $\mathrm{Al}$ concentrations among different landforms of similar parent material, in a landform context.

\section{Materials and methods}

\section{Catchment description}

The Ashburton Lakes catchment is located on the eastern side of New Zealand's Southern Alps, inland from Mt Somers. The catchment encompasses two inter-montane basins, Lake Heron and Lake Clearwater, and is flanked by high mountain ranges. The valley floor ranges in elevation from $500-800 \mathrm{~m}$ a.s.l. The study area was selected based on several criteria: i) the catchment contains valley-floor landforms commonly farmed in the high-country, ii) there is a distinct rainfall gradient and iii) the age of the land surfaces have been well defined in previous work in this area (Barrell et al. 2011). Landforms were classified according to their mode of origin (e.g. glacial or alluvial) and age. Soil parent materials comprised solely greywacke-derived regoliths including alluvium, till and loess. Catchment sampling was mainly from Acidic Orthic Brown soils plus two classified as Typic Orthic Brown soils (Hewitt 
2010). Landform was considered to be a proxy for subtle differences in soil characteristics engendered by differences in age, topography and soil parent material texture, not captured by soil taxa.

\section{Site selection}

Twenty one sites were selected by stratifying the landscape according to geomorphological maps, digital elevation models (DEM) and maps of climate variables (NIWA Core funded project Climate Present and Past CAOA1501). There was replication at sample sites within a landform (five replicates). Sites differed in median annual rainfall, landform age and type, elevation, aspect and land-use (Table 1).

\section{Soil sampling collection methods}

Field soil sampling was conducted between 2014 and 2016 at the 21 sites. Soil samples were taken from a single soil pit at each site; samples were taken as $5 \mathrm{~cm}$ contiguous vertical increments yielding about $200 \mathrm{~g}$ of soil each (to $65 \mathrm{~cm}$ or gravels).

\section{Laboratory methods}

Soil samples were analysed for $\mathrm{pH}\left(\mathrm{H}_{2} \mathrm{O}\right)(1: 2.5$ soil: water ratio) (Blakemore et al. 1987) and extractable $\mathrm{Al}$, using the $0.02 \mathrm{M} \mathrm{CaCl}_{2}$ extraction method, and quantified using inductively coupled plasma atomic emission spectroscopy (ICP-OES: Varian 720-ES ICPOES; Varian Inc., Victoria, Australia) analysis.

\section{Statistical analysis}

Data were analysed using a series of general linear models in Genstat version 16.0, to determine if there was a significant difference in the soil $\mathrm{pH}$ and extractable $\mathrm{Al}$ across different rainfall zones, landform age and type. For the effect of depth, a linear mixed model was constructed, because unlike the other factors, profile depth differed within a single site. Site was used as a random variable to remove the effect of site similarities, so depth could be compared across sites. Extractable Al was log transformed for analysis to achieve normal distribution and satisfy model assumptions. The Akaike information co-efficient value (AIC) was used to

Table 1 Site information for the 21 sites sampled in the Ashburton Lakes catchment including site code, landform type, geologic age, median annual rainfall (MAR), median annual temperature (MAT), elevation and land-use.

\begin{tabular}{|c|c|c|c|c|c|c|}
\hline Site code* & Landform & Geologic Age & $\begin{array}{c}\text { MAR } \\
\text { (mm/year) }\end{array}$ & $\begin{array}{l}\text { MAT } \\
\left({ }^{\circ} \mathrm{C}\right)\end{array}$ & $\begin{array}{l}\text { Elevation } \\
\text { (m a.s.I.) }\end{array}$ & Land-use \\
\hline $\mathrm{AF} 1$ & alluvial fan & Holocene (<11.7 kyr) & 1512 & 8.7 & 745 & DOC \\
\hline MO8 & alluvial fan & Holocene (<11.7 kyr) & 1529 & 8.4 & 771 & Farmland \\
\hline AF3 & alluvial fan & Holocene (<11.7 kyr) & 1169 & 8.8 & 693 & Farmland \\
\hline AF4 & alluvial fan & Holocene (<11.7 kyr) & 1449 & 8.5 & 819 & Farmland \\
\hline AF5 & alluvial fan & Holocene (<11.7 kyr) & 1207 & 8.7 & 741 & Farmland \\
\hline OF2 & outwash surface & Latest Late Otiran (19-14.5 kyr) & 1137 & 9.2 & 624 & DOC \\
\hline MO1 & outwash surface & Latest Late Otiran (19- $14.5 \mathrm{kyr})$ & 1180 & 8.8 & 702 & Farmland \\
\hline MO7 & outwash surface & Late Otiran (45 -14.5 kyr) & 1479 & 8.7 & 752 & Farmland \\
\hline OF3 & outwash surface & Latest Late Otiran (19-14.5 kyr) & 1282 & 8.6 & 747 & DOC \\
\hline OF4 & outwash surface & Latest Late Otiran (19-14.5 kyr) & 1403 & 7.9 & 860 & DOC \\
\hline OF5 & outwash surface & Latest Late Otiran (19-14.5 kyr) & 1288 & 8.8 & 689 & DOC \\
\hline OF1 & moraine & Late Otiran (45 -14.5 kyr) & 1128 & 9.0 & 657 & DOC \\
\hline MO2 & moraine & Late Otiran (45 -14.5 kyr) & 1290 & 8.9 & 703 & DOC \\
\hline $\mathrm{MO3}$ & moraine & Early Otiran or Older (360 -45 kyr) & 1332 & 8.8 & 749 & $\mathrm{DOC}$ \\
\hline MO4 & moraine & Latest Late Otiran (19-14.5 kyr) & 1502 & 8.4 & 811 & Farmland \\
\hline MO5 & moraine & Latest Late Otiran (19- $14.5 \mathrm{kyr}$ ) & 1522 & 8.0 & 929 & Farmland \\
\hline MO6 & moraine & Latest Late Otiran (19- $14.5 \mathrm{kyr})$ & 1558 & 8.7 & 734 & Farmland \\
\hline MO9 & moraine & Late Otiran (14.5 - $45 \mathrm{kyr})$ & 1500 & 7.6 & 988 & Farmland \\
\hline MO10 & moraine & Latest Late Otiran (19-14.5 kyr) & 1260 & 8.4 & 736 & DOC \\
\hline MO11 & moraine & Latest Late Otiran (19- 14.5 kyr) & 1273 & 8.8 & 678 & DOC \\
\hline MO12 & moraine & Latest Late Otiran (19- $14.5 \mathrm{kyr}$ ) & 1271 & 8.8 & 696 & DOC \\
\hline
\end{tabular}

Note: The MAR and MAT were determined using NIWA annual 50th percentile climate data for each of the sites using GPS coordinates (National Institute of Water and Atmospheric Research, 2015). Aspect was derived from a DEM with $8 \mathrm{~m}$ resolution (LINZ, 2012). Elevation is measured in metres above sea level (m a.s.I). * For several site codes, the lettering does not correspond correctly to the landform the site was on. This was due to plotting the GPS co-ordinates of the site after sampling and the landform changing in some circumstances. In the Geologic age column the number in brackets refers to the estimated age (approximate 1000 years, kyr) of the land surface (Barrell et al., 2011). 
determine the fit and explanatory power of each model. A lower AIC implies a better fitting model and higher explanatory value (Akaike 1974; Sokal \& Rohlf 2012). Single models and combination models of different factors were compared to determine if a single factor or a combination of factors was best for predicting $\mathrm{pH}$ and Al concentration. A two-sample (two-sided) t-Test was conducted on samples from the top $20 \mathrm{~cm}$ of the soil profile, and there was no difference in the mean $\log \mathrm{Al}$ concentration between the two land uses (Department of Conservation (DOC) and farmed) and, as such, the effect was not considered in the linear model or decision tree analysis.

Decision trees (non-parametric test) were created in $\mathrm{R}$ (a software environment for statistical computing and graphics, Version 3.3.1). This technique was a tool to establish the relative importance of the predictor variables in explaining the response and the relationships between predictor (rainfall, age, landform, elevation, aspect and slope) and response variables ( $\mathrm{pH}$ and extractable $\mathrm{Al}$ ) in the $20 \mathrm{~cm}$ depth zone (top 20 $\mathrm{cm}$ of the soil profile and is most important for plant roots). The set of rules established in the decision tree were used to produce a catchment map using ArcPro software (version 2.0.1) of soil extractable Al for the $20 \mathrm{~cm}$ depth zone (Figure 2). Decision trees were also constructed for the other depth zones, but were not included in this paper (Whitley 2018). Results from deeper depth increments showed similar driving variables, but in different order of importance.

\section{Results}

\section{Depth in the soil profile}

The soil extractable $\mathrm{Al}\left(0.02 \mathrm{M} \mathrm{CaCl}_{2}\right)$ concentration ranged from $1.2-39.1 \mathrm{mg} / \mathrm{kg}$ (mean $7.8 \mathrm{mg} / \mathrm{kg}$ ) and the soil $\mathrm{pH}$ 4.7-6.0. Depth was the strongest explanatory variable $(\mathrm{P}<0.001)$ for $\mathrm{pH}$ and $\mathrm{Al}$ concentration; however, there was considerable variation within a given depth increment among sites and the depthfunction models had low $\mathrm{R}^{2}$ values (Table 2; Figure 1).

Soils were more acidic in the top of the soil profile, with an expected value (mean) of 5.3 at $5 \mathrm{~cm}$ and $10 \mathrm{~cm}$, increasing with depth to 5.4 at $50 \mathrm{~cm}$ and 5.6 at $80 \mathrm{~cm}$ (Figure 1a). Soil $\mathrm{pH}$ at any given depth varied by as much as $1.1 \mathrm{pH}$ units and the variance declined with depth.

In the pooled data, the $\mathrm{Al}(0.02 \mathrm{M} \mathrm{CaCl})_{2}$ concentration was higher in the top of the soil profile, with expected mean values of $8.4 \mathrm{mg} / \mathrm{kg}$ and $7.1 \mathrm{mg} / \mathrm{kg}$ at $5 \mathrm{~cm}$ and $10 \mathrm{~cm}$, respectively, declining to $5.1 \mathrm{mg} / \mathrm{kg}$ at $50 \mathrm{~cm}$ and $3.6 \mathrm{mg} / \mathrm{kg}$ at $80 \mathrm{~cm}$ (Figure $1 \mathrm{~b}$ ). However, individual soil profiles varied from this pattern showing constant, increasing, decreasing or curved trends with depth. The $\mathrm{Al}\left(0.02 \mathrm{M} \mathrm{CaCl}_{2}\right)$ concentration at any given depth varied by as much as $36.5 \mathrm{mg} / \mathrm{kg}$. Linear mixed models emphasised that the addition of other factors complicated the model (higher AIC) and did not improve the outcome from a single factor model (depth) for $\mathrm{pH}$ and extractable $\mathrm{Al}$.

\section{Landform age}

There was a strong difference $(\mathrm{P}<0.001)$ in the soil $\mathrm{pH}$ and extractable $\mathrm{Al}\left(0.02 \mathrm{M} \mathrm{CaCl}_{2}\right)$ concentration measured across the different age surfaces (Table 2). The mean $\mathrm{pH}$ value for sites in both the Latest Late Otiran and the Early Otiran, or older, were the lowest at 5.3. These surfaces also had the highest mean extractable $\mathrm{Al}$ concentrations of $7.3 \mathrm{mg} / \mathrm{kg}$ and $8.6 \mathrm{mg} /$ $\mathrm{kg}$, respectively. There was no systematic trend of $\mathrm{pH}$ or extractable $\mathrm{Al}$ with increasing landform age (Table 2).

\section{Landform type}

There was a small difference $(\mathrm{P}<0.001)$ in the mean soil $\mathrm{pH}$ among the different landforms (Table 2). The mean $\mathrm{pH}$ was highest on alluvial fans at 5.5, and slightly lower at 5.4 on the outwash surfaces and moraines. There was no difference in mean extractable $\mathrm{Al}(0.02 \mathrm{M}$ $\mathrm{CaCl}_{2}$ ) concentration among landforms.

\section{Rainfall}

Soil $\mathrm{pH}$ showed a linear trend $(\mathrm{P}<0.05)$ of increasing with increasing rainfall, but the relationship had low explanatory power $\left(\mathrm{R}^{2}=0.02\right.$, Table 2$)$. At any given rainfall $\mathrm{pH}$ varied by as much as 0.7 units. The $\mathrm{Al}$ $(0.02 \mathrm{M} \mathrm{CaCl})$ concentration showed a trend $\left(\mathrm{R}^{2}=\right.$ $0.03, \mathrm{P}<0.01)$ of decreasing $\mathrm{Al}$ concentration with increasing rainfall (Table 2). At a given rainfall the $\mathrm{Al}$ concentration varied by as much as $30.4 \mathrm{mg} / \mathrm{kg}$. The high variance in soil $\mathrm{pH}$ and extractable $\mathrm{Al}$ at a given rainfall implies there are other factors involved.

\section{Patterns of $\mathrm{pH}$ and extractable $\mathrm{Al}$ in the Ashburton Lakes Catchment}

Decision trees identified that rainfall was the most important factor for soil $\mathrm{pH}$ in the $20 \mathrm{~cm}$ depth zone, followed by elevation and aspect. There was a large area in the south of the catchment with rainfall $<1174 \mathrm{~mm} /$ year, where soils had a mean $\mathrm{pH}$ of 5.6. The most acidic soils were identified as a band through the centre of the catchment from east to west, and an area surrounding Lake Heron, where rainfall was $\geq 1174 \mathrm{~mm} /$ year and are positioned on the valley floor $(<699.1 \mathrm{~m}$ a.s.l).

Rainfall was the most important factor determining soil $\mathrm{Al}\left(0.02 \mathrm{M} \mathrm{CaCl}_{2}\right)$ concentration in the top $20 \mathrm{~cm}$, followed by aspect (Figure 2). The higher concentrations in the catchment were found at rainfall $\geq 1266 \mathrm{~mm} /$ year and seem to mirror the areas that were identified as most acidic. The lowest $\mathrm{Al}$ concentrations, with a mean $\mathrm{Al}$ of $3.8 \mathrm{mg} / \mathrm{kg}$ are in areas with $<1266$ $\mathrm{mm} /$ year rainfall and south facing sites. 


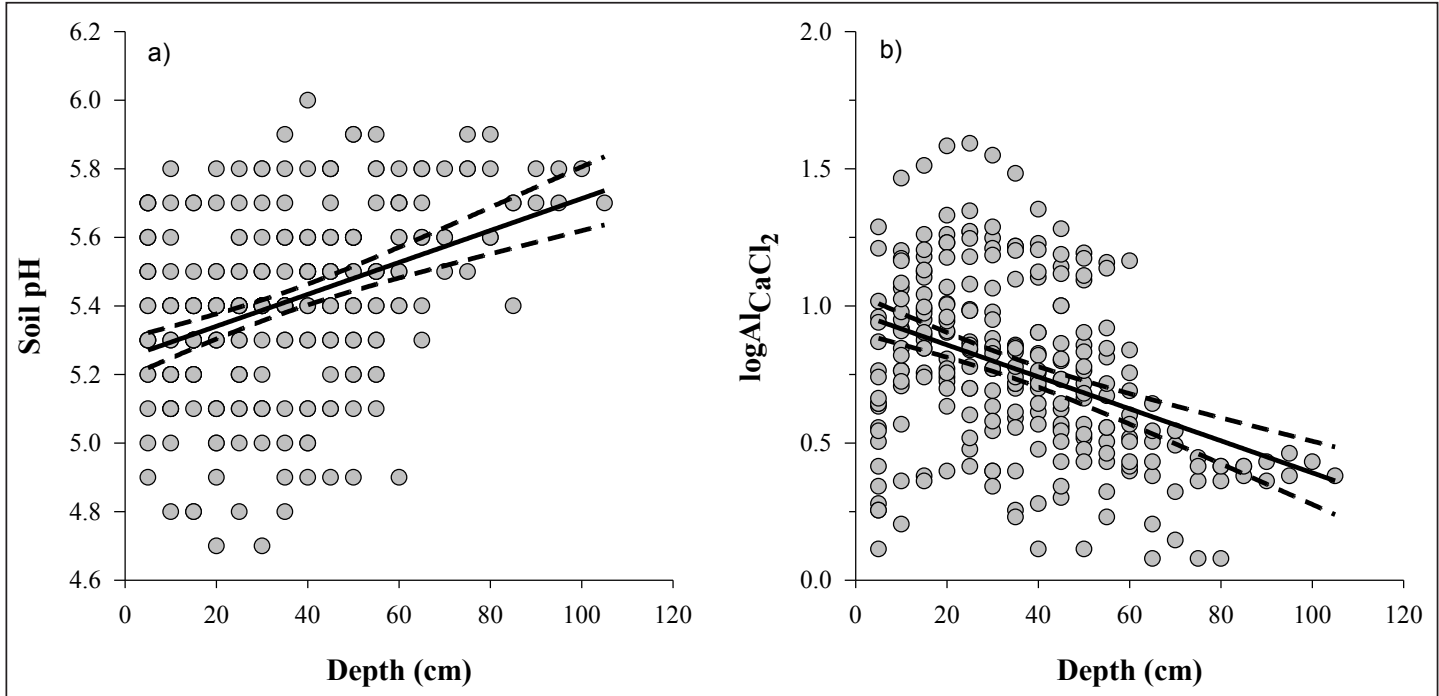

Figure 1 Soil pH a) and log soil $\mathrm{Al}\left(0.02 \mathrm{M} \mathrm{CaCl}_{2}\right)$ b) against soil depth for the 21 sites from the Ashburton Lakes catchment, Canterbury, New Zealand. Forms of the regressions (solid black lines) are: a) $\mathrm{pH}=5.25( \pm 0.029)+0.0047( \pm 0.0007) \times\left(\mathrm{R}^{2}=0.15\right)$ and $\left.\mathrm{b}\right)$ log soil $A l=0.98( \pm 0.036)-0.0058( \pm 0.0009) \times\left(R^{2}=0.15\right)$. Values reported in brackets are standard errors of the parameters. Dashed lines represent the $95 \%$ confidence intervals.

Table 2 Mean soil $\mathrm{pH}$ and extractable $\mathrm{Al}\left(0.02 \mathrm{M} \mathrm{CaCl}_{2}, \mathrm{mg} / \mathrm{kg}\right)$ across different landforms and aged surfaces in the Ashburton Lakes Catchment and the significance $(\mathrm{P}$ values) of landform, age of the surface, rainfall and depth for predicting soil $\mathrm{pH}$ and $\mathrm{Al}\left(0.02 \mathrm{M} \mathrm{CaCl}_{2}\right)$ from the 21 sites sampled in this catchment.

\begin{tabular}{|c|c|c|c|c|c|}
\hline \multirow[b]{2}{*}{ Landform } & \multicolumn{3}{|c|}{ Expected values (mean) } & \multirow[b]{2}{*}{ SEM } & \multirow[b]{2}{*}{$\mathrm{Al}(\mathrm{mg} / \mathrm{kg})$} \\
\hline & $\mathrm{pH}$ & SEM & LogAl & & \\
\hline alluvial fan & 5.5 & 0.03 & 0.74 & 0.04 & 5.5 \\
\hline outwash surface & 5.4 & 0.03 & 0.76 & 0.04 & 5.8 \\
\hline moraine & 5.4 & 0.02 & 0.79 & 0.03 & 6.2 \\
\hline $\mathrm{P}$ value (Landform) & $<0.001$ & & 0.612 & & \\
\hline Age of surface & $\mathrm{pH}$ & SEM & LogAI & SEM & Al $(\mathrm{mg} / \mathrm{kg})$ \\
\hline Holocene & 5.5 & 0.03 & 0.74 & 0.04 & 5.5 \\
\hline Latest Late Otiran & 5.3 & 0.02 & 0.86 & 0.03 & 7.3 \\
\hline Late Otiran & 5.6 & 0.02 & 0.56 & 0.04 & 3.7 \\
\hline Early Otiran or older & 5.3 & 0.04 & 0.94 & 0.05 & 8.6 \\
\hline$P$ value (Age) & $<0.001$ & - & $<0.001$ & - & - \\
\hline $\mathrm{P}$ value (Rainfall) & $<0.05$ & - & $<0.01$ & - & - \\
\hline$P$ value (depth) & $<0.001$ & - & $<0.001$ & - & - \\
\hline
\end{tabular}

Values in the table are from general linear models that determined the significance of landform type, age of the surface and rainfall for soil $\mathrm{pH}$ and $\mathrm{Al}$ concentrations in this catchment. All Al concentrations are $0.02 \mathrm{M} \mathrm{CaCl}_{2}$ extractable. The $\mathrm{Al}$ is the back-transformed $\mathrm{Al}$ concentration from the log output. For depth, the $\mathrm{P}$ values are from a General Linear Mixed Model (with site as a random variable) that determined the significance of depth for soil $\mathrm{pH}$ and $\mathrm{Al}$ concentrations in this catchment.

\section{Discussion}

Depth was the strongest explanatory variable for $\mathrm{pH}$ and $\mathrm{Al}\left(0.02 \mathrm{M} \mathrm{CaCl}_{2}\right)$. In the pooled data set soil $\mathrm{pH}$ increased with depth in the soil profile and $\mathrm{Al}$ declined (Figures 1a and 1b). Harrison et al. (1990) reported similar trends - an increase in soil $\mathrm{pH}$ with depth in the soil profile for a sequence of terrace soils and a decline in extractable $\mathrm{Al}$ (1 M KCl extracted $\mathrm{Al})$ for terrace and moraine soils, particularly below $40-50 \mathrm{~cm}$. Eger \& Hewitt (2008) also found that the soil $\mathrm{pH}$ increased with depth in the soil profile for eight hillslope sites in the Canterbury highcountry. However, the pooled data set trend masks strong inter-profile variability in depth trends of $\mathrm{Al}\left(0.02 \mathrm{M} \mathrm{CaCl}_{2}\right)$. The factors determining the depth variability remain unknown.

Extractable Al $(0.02 \mathrm{M}$ $\mathrm{CaCl}_{2}$ ) was measured at concentrations that would be toxic to legumes, ranging 


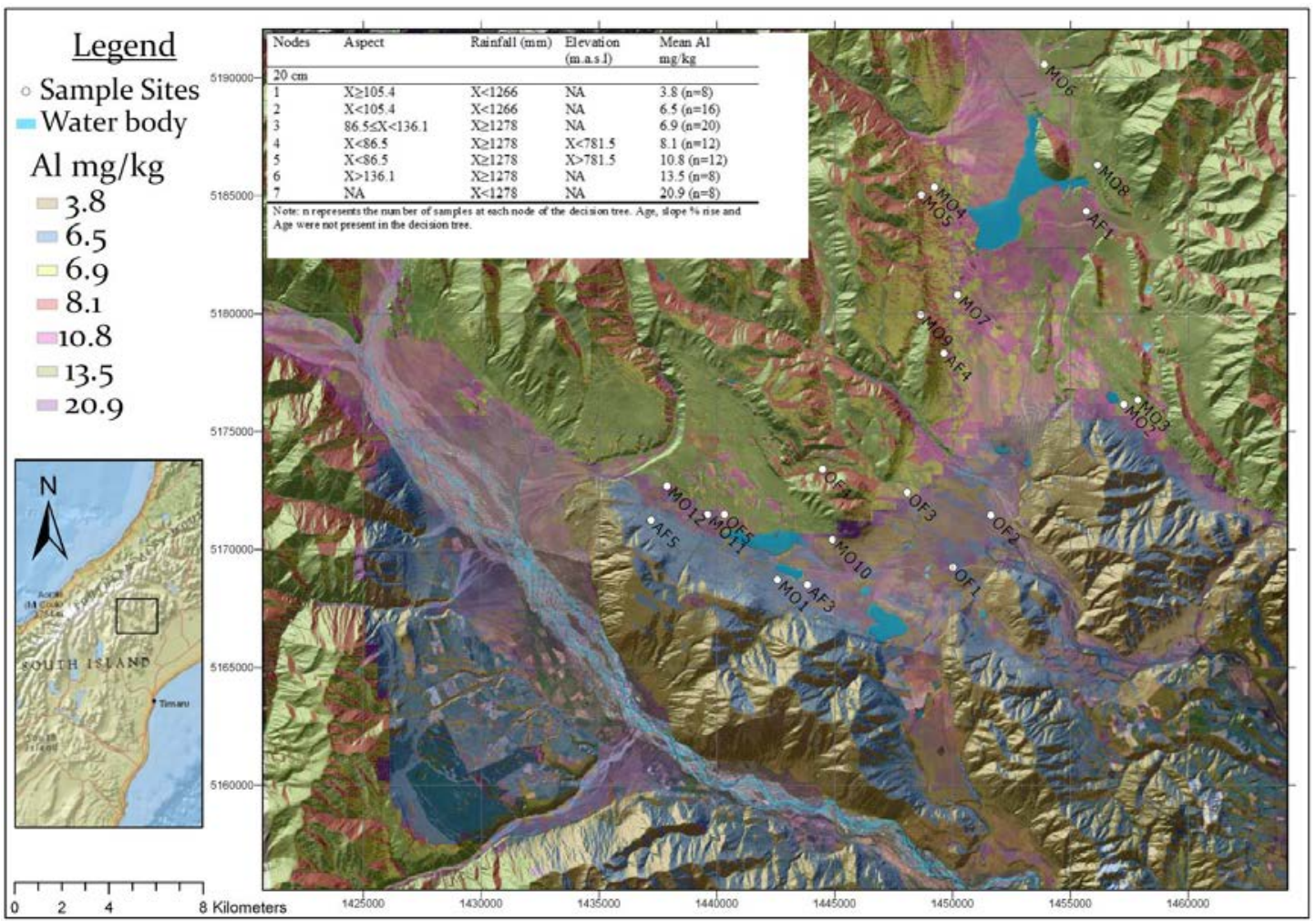

Figure 2 A map of mean extractable $\mathrm{Al}\left(0.02 \mathrm{M} \mathrm{CaCl}_{2}\right)$ concentration for $0-20 \mathrm{~cm}$ depth in the Ashburton Lakes catchment, constructed using rules from the decision tree analysis. The table contains a list of rules associated with each node of the decision tree for soil $\mathrm{Al}$ for the $20 \mathrm{~cm}$ depth zone. To view this map in colour visit the hyperlink to the online version.

from $1.2 \mathrm{mg} / \mathrm{kg}$ to $39.1 \mathrm{mg} / \mathrm{kg}$ (mean $7.8 \mathrm{mg} / \mathrm{kg}$ ). Despite the overall trend of decreasing $\mathrm{Al}$ concentration with depth, even at a depth of $80 \mathrm{~cm}$ the mean $\mathrm{Al}$ concentration was $3.6 \mathrm{mg} / \mathrm{kg}$ and likely to be 'toxic' for lucerne and other sensitive legumes, as the threshold for toxicity is species specific (Moir et al. 2016). These results highlight that surface soil samples $(<20 \mathrm{~cm})$ are inadequate for an assessment of potential $\mathrm{Al}$ toxicity and that soil sampling should go to a depth of $80 \mathrm{~cm}$, if possible, to be able to advise the farmer on legume selection.

The general linear models, which used the whole data set, showed no strong landscape patterns of $\mathrm{pH}$ and extractable $\mathrm{Al}$, perhaps because those patterns were overwhelmed by strong depth variability.

There were some differences in $\mathrm{Al}\left(0.02 \mathrm{M} \mathrm{CaCl}_{2}\right)$ and $\mathrm{pH}$ with landform age, but it didn't systematically change with the age of the surface. This was in contrast to a chronosequence study by Harrison et al. (1990) which showed consistent increases in extractable $\mathrm{Al}$ (1 $\mathrm{M} \mathrm{KCl}$ extracted $\mathrm{Al}$ ) concentration and decreases in $\mathrm{pH}$ for soils on progressively older landforms along two development sequences. Potential explanations for the contrasts is the lack of uniformity of other soil forming factors (e.g. slope, aspect) and erosion/ depositional history that were more tightly controlled in the chronosequence study.

Differences in $\mathrm{pH}$ among landform types were found, in contrast to no difference in $\mathrm{Al}\left(0.02 \mathrm{M} \mathrm{CaCl}_{2}\right)$ concentrations, which was an unexpected finding (Table 2). The only landform-related distinction was a higher $\mathrm{pH}$ on alluvial fans, which is presumably related to the relative youth of these landforms compared to glacial-age moraines and outwash terraces.

Rainfall was an important factor for $\mathrm{pH}$ and $\mathrm{Al}$ $\left(0.02 \mathrm{M} \mathrm{CaCl}_{2}\right)$ values in this catchment. However, the relationship was weak and showed the opposite trend to that in other New Zealand climosequence studies. Webb et al. (1986) and Harrison et al. (1990) reported declines in soil $\mathrm{pH}$ and increases in soil $\mathrm{Al}(1 \mathrm{M} \mathrm{KCl}$ extracted $\mathrm{Al})$ concentration with increasing rainfall for a transect of moraines near Lake Pukaki (640-2000 mm/year) and two chronosequences under different rainfall on moraine and terrace soils near Craigieburn, Canterbury. Increased soil acidification and $\mathrm{Al}(1 \mathrm{M} \mathrm{KCl}$ extracted Al) was observed at the higher rainfall sites in these two studies, which was linked to more intense weathering, greater soil development, leaching and the reduction in bases on the cation exchange sites. Current results are 
attributed to a relatively narrow range of rainfall in the study area (ca $450 \mathrm{~mm}$ ) and the rainfall being above the threshold ( $800 \mathrm{~mm} /$ year) at which a major shift in soil leaching and weathering occurs (Dixon et al. 2016). Thus, the relationship between MAR-pH and MAR-Al identified here may be simple correlation due to some indirect relationship, not causation.

Decision tree analysis used only the $20 \mathrm{~cm}$ depth zone data to remove any influence of strong depth variation of $\mathrm{pH}$ and extractable Al. Distinct areas with higher extractable $\mathrm{Al}$ concentrations were identified that seem to mirror the areas identified as most acidic in the catchment (Figure 2). Rainfall ( $\geq 1174 \mathrm{~mm} /$ year) at sites located at lower elevations in the catchment $(<699 \mathrm{~m}$ a.s.l) and southerly aspects, had more acidic soils with more $\mathrm{Al}\left(0.02 \mathrm{M} \mathrm{CaCl}_{2}\right)$ in the $20 \mathrm{~cm}$ depth zone. Rainfall was important and trends were similar to those found in the studies discussed above (Figure 2). The influence of aspect on acidity and $\mathrm{Al}$ concentration is consistent with other findings (Eger \& Hewitt 2008). Their study found stronger leaching, enhanced weathering and acidification on south-facing slopes and higher oxalate extractable $\mathrm{Al}$ concentrations. Their measure of $\mathrm{Al}$ was different to the $\mathrm{Al}\left(0.02 \mathrm{M} \mathrm{CaCl}_{2}\right)$ used in this study; however, the expectation is that the $\mathrm{Al}\left(0.02 \mathrm{M} \mathrm{CaCl}_{2}\right)$ is higher at the lower $\mathrm{pH}$ sites (south-facing) under greater weathering conditions, although this was not tested.

Decision tree analysis suggests, that when the overwhelming depth variability of extractable $\mathrm{Al}$ was isolated, then the variability of $\mathrm{Al}$ was spatially structured according to landscape and environmental attributes (rainfall, elevation, aspect). Although the characteristics of the spatial structure may be unique to the Ashburton Lakes area, or limited to a subset of the South Island high-country, this study provides support for continuing this line of research. Landscape models of extractable $\mathrm{Al}$ in a range of settings would provide a valuable decision support mechanism for farmers when determining which areas could be targeted for development and which are unsuitable, either by avoiding or mitigating soil $\mathrm{Al}$ concentrations.

\section{ACKNOWLEDGEMENTS}

Ballance Agri-Nutrients Ltd provided funding for this research. Miriam Hodge provided statistical advice and support. Sephrah Rayner, Lyn Carmichael and Natasha Barbier assisted in fieldwork in association with Landcare Research Ltd. Lynne Clucas for ICPOES analysis. The farmers and farm managers in the Ashburton Lakes catchment including Philip Todhunter, Donald Whyte, Philip Wareing, Gene Thomas and Brian May, and DOC, who gave permission for sampling on their land. NIWA Core funded project Climate Present and Past CAOA1501 provided the rainfall and temperature datasets.

\section{REFERENCES}

Akaike, H. 1974. A new look at the statistical model identification. IEEE Transactions on Automatic Control 19: 716-723.

Barrell, D.J.A.; Andersen, B.G.; Denton, G.H. 2011. Glacial geomorphology of the central South Island, New Zealand. GNS Science Monograph 27.

Barrell, D.J.A.; Andersen, B.G.; Denton, G.H.; Smith Lyttle, B. 2013. Glacial geomorphology of the central South Island, New Zealand. GNS Science Monograph 27a (Explanatory notes).

Blakemore, L.C.; Searle, P.L.; Daly, B.K. 1987. Methods for chemical analysis of soils. Vol. 80. Soil Bureau, Lower Hutt, New Zealand.

Dixon, J.L.; Chadwick, O.A.; Vitousek, P.M. 2016. Climate-driven thresholds for chemical weathering in postglacial soils of New Zealand. Journal of Geophysical Research-Earth Surface 121: 16191634. doi:10.1002/2016jf003864.

Eger, A.; Hewitt, A. 2008. Soils and their relationship to aspect and vegetation history in the eastern Southern Alps, Canterbury High Country, South Island, New Zealand. Catena 75: 297-307.

Harrison, R.; Swift, R.S.; Campbell, A.S.; Tonkin, P.J. 1990. A study of two soil development sequences located in a montane area of Canterbury, New Zealand, I. Clay mineralogy and cation exchange properties. Geoderma 47: 261-282.

Haynes, R.J.; Williams, P.H. 1993. Nutrient cycling and soil fertility in the grazed pasture ecosystem. Advances in Agronomy 49: 119-199.

Hewitt, A.E. 2010. New Zealand Soil Classification. $3^{\text {rd }}$ Edition. Lincoln, New Zealand, Manaaki Whenua Press, p.135.

Moir, J.; Jordan, P.; Moot, D.J.; Lucas, R.J. 2016. Phosphorus response and optimum $\mathrm{pH}$ ranges of twelve pasture legumes grown in an acid upland New Zealand soil under glasshouse conditions. Journal of Soil Science and Plant Nutrition 16: 438-460.

Sokal, R.R.; Rohlf, F.J. 2012. Multiple and curvilinear regression. pp. 651-652. In: Biometry: the principles and practice of statistics in biological research (4th ed.). W.H. Freeman and Company: New York, USA.

Webb, T.H.; Campbell, A.S.; Fox, F.B. 1986. Effect of rainfall on pedogenesis in a climosequence of soils near Lake Pukaki, New Zealand. New Zealand Journal of Geology and Geophysics 29: 323-334.

Whitley, A.E. 2018. Investigations of soil extractable aluminium and toxicity in New Zealand soils. Unpublished $\mathrm{PhD}$ thesis. Lincoln University, Christchurch, New Zealand. 265 pp. 